\title{
Ethnic Intermarriage in Croatia with Special Emphasis on the Czech Minority
}

\author{
Snježana Mrdjen ${ }^{A *}$, Maja Bahnik ${ }^{B}$ \\ Received: March 20, 2018 | Revised: June 8, 2018 | Accepted: June 11, 2018
}

DOI: $10.5937 / 22-16884$

\begin{abstract}
This article analyzes interethnic marriage in Croatia in terms of nationality throughout a forty-five year period (1970-2015) on the basis of vital statistics with special consideration of the Czech minority. The usual method of endogamy/exogamy percentage and the odds ratio method were applied. The results show that the percentage of endogamous marriages in Croatia has significantly risen after 1991. Different ethnic groups display various attitudes towards endogamy, ranging from 15 to over 90 percent. Along with Italians, Hungarians and Slovaks, Czechs are less endogamous than other national minorities. Gender differences, contrary to the conclusions in the literature, show that Czech men enter into marriage outside their group less often than Czech women. The change of political climate in Croatia during the 1990 s resulted not only in the increase of endogamy, but also affected the structure of mixed marriages among Czechs.
\end{abstract}

Keywords: Intermarriage, endogamy, ethnicity, gender differentials, Czechs, Croatia

\section{Introduction}

Ever since the early 2 oth century numerous sociologists have studied marriage in terms of ethnic origin, analyzing spouse choice and looking into the reasons for marrying within the same ethnic group or choosing a spouse from a different group (Kalmijn, 1998; Van Tubergen \& Mass 2007). Ethnic intermarriages are the best indicator of the frequency of direct social interaction between various ethnic groups in society and are indicative of social acceptance of diversity (RodrìgezGarcìa, 2015; Smits, 2010; Qian at al., 2012). They demonstrate the level of integration and socio-cultural homogenization, or in contrast, the segregation between groups (Botev, 1994; Lachance, 1982). The term endogamy/homogamy designates marriage between two people from the same ethnic community or some other category, whereas exogamy/heterogamy refers to marriage outside one's own community (Rosenfeld, 2008).
Interethnic marriages (marriage between the members of different ethnicities/ethnic groups) in the territory of former Yugoslavia and newly formed states, the analysis of marriage procedure and structure, the nationality of children from mixed marriages - these topics were mostly covered by the authors from the region (Petrović, 1966, 1985, 1989; Mrdjen, 1996, 2000a, 20oob; Mrđen, 2010; Morokvašić-Müller, 2004; Petrović, M., 1997) and also by some Western European authors (Botev, 1994; Bromlei \& Kashuba, 1982; Le Goff \& Giudici, 2009, 2014; Smits, 2010). This paper provides, for the first time, an analysis of mixed marriages among Czechs in Croatia and a comparative overview including other nationalities over a period spanning more than four decades.

Former Yugoslavia emerged in a region populated for centuries by over 20 ethnicities with different

\footnotetext{
A Department of Geographie, University of Zadar, Ul. Franje Tudjmana 24i, 23000 Zadar, Croatia, e-mail: smrdjen@unizd.hr

B Department of Tourism and Communication Studies, University of Zadar, Ul. Franje Tudjmana 24i, 23000 Zadar, Croatia, e-mail: majabahnik@gmail.com

* Corresponding author: Snježana Mrdjen, e-mail: smrdjen@unizd.hr
} 
historical, linguistic, religious and socio-economic characteristics. Except in Slovenia (where the majority nationality was represented with over $90 \%$ in the total population) and in Serbia without autonomous provinces ( $80 \%$ in the total population), the ethnic structure in other republics and provinces was bimodal (Montenegro, Croatia ${ }^{1}$, Macedonia, Kosovo), trimodal (Bosnia-Herzegovina) or plurimodal (Vojvodina). All nationalities, regardless of which republic they lived in and regardless of their percentage in the total population, had the same rights (individually, politically, socially and economically) that were guaranteed by the Constitution ${ }^{2}$. Every citizen of the Socialist Federal Republic of Yugoslavia was free to state which nationality or national minority they belong to, but was under no obligation to make any declaration on this matter, nor did they have to, under the Article 170 of the Constitution, to choose to belong to one of the nationality or national minorities. Nationality could be declared freely (self-declaration) and it did not go on record in identity documents as, for example, in the Soviet Union or Russia before 1997 (Gorenburg, 2006). This means that the same person was able to declare different nationality in a census or when they entered into marriage or filed for divorce (Mrđen, 2002). In this case we are dealing with "ethnic transfer", which is more typical of smaller rather than larger ethnic groups (Mrdjen, 2000a, p. 109). As far as lan-

1 It was only after the 2001 census that the number of Croats as the majority nationality rose above $80 \%$ in the total population.

2 The basic principle of the Article 154 of the Constitution of the Socialist Federal Republic of Yugoslavia from 1974 was: "Citizens shall be equal in their rights and duties regardless of nationality, race, sex, language, religion, education or social status". guage is concerned, proficiency in Serbian-Croatian/ Croatian-Serbian (that was not the only official language, but was spoken by the majority of population), was mandatory in elementary education, but spoken and written languages of all the nationalities were official in the Yugoslav territory and defined in the constitutions of each respective republic (Klopčić, 1992).

After sovereign states were constituted in the territory of former Yugoslavia, the position of minority ethnic groups was no longer the same: differences appeared between the majority nationality and all other nationalities, which were now granted national minority status. According to the Constitutional Act on the Rights of National Minorities in Croatia, a change, or rather, a reduction of certain rights occurred in comparison to the rights that national minorities had in Yugoslavia. In addition to this, Yugoslav nationalities, such as Serbians, Montenegrins, Slovenians, Macedonians and Bosniaks in Croatia became national minorities, or, Djurdjev at al. (2009) use the term "new" minorities.

These new circumstances after 1991, which resulted in reduced rights for certain nationalities, combined with aggravated interethnic relations after the war in the 1990 (Morokvašić-Müller, 2004), especially between Croats and Serbs, had a definite impact on mutual relationships between majority nationality groups with all others, which was also reflected in the number of interethnic marriages. And so in all the states that emerged in the territory of former Yugoslavia homogamy became the prevalent characteristic of interethnic relations (Mrđen, 2010). This became particularly obvious in Croatia as early as 1990, where the political climate affected the frequency of interethnic marriages and partner choice more than in other former Yugoslav republics.

\section{Historical and political background - Czech minority in Croatia}

Members of the Czech minority in the territory of what is now Croatia are descendants of the colonists who were settling there in various periods from the end of $18^{\text {th }}$ century to 1920 (Dugački, 2013; Horina, 2013). Still, it was not until late 1870 s that we could speak of any large-scaled organized Czech colonization (Pepeonik, 1967; Matušek, 1996). That was when colonization, very significant at the time, took part. It was primarily spurred on by agricultural crisis and great disparity in population density between the regions in Croatia and those in Moravia and the Czech lands, which is where most of the colonists emigrated from (Pepeonik, 1967; Herout, 2008). The colonization was facilitated by the fact that both Czechs and Croats lived in the common state Austria-Hungary/the Habsburg
Monarchy at the time. Auerhan, the greatest expert on Czech and Slovak settlements outside of Czechoslovakia, according to Pepeonik (1967, p. 56), "says that the earliest Czech settlements emerged in the last years of the 19th and early years of the 2oth century, when several Czech families immigrated from Russia after refusing the request of imperial authorities to convert to Orthodox Christianity."

According to official census data from the late 19th century (1880), there were 14,584 people living in Croatia whose mother tongue was $\mathrm{Czech}^{3}$, and their num-

\footnotetext{
3 This number did not take into account children under two years of age because the criterion for the census was mother tongue and not ethnic origin.
} 


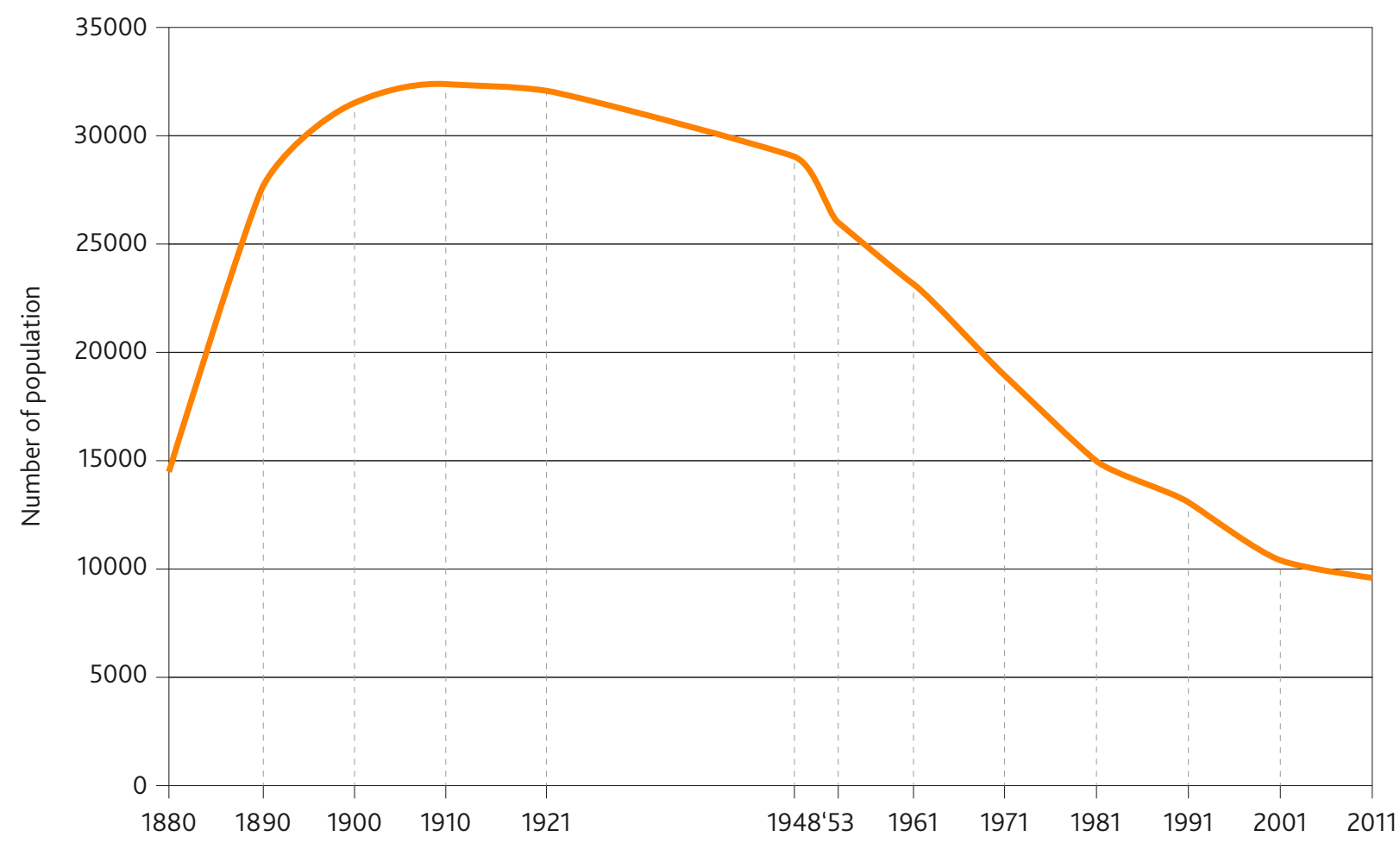

Figure 1. Number of Czechs population according to the censuses in Croatia, 1880-2011

Note: Data for the population census from 1931 is missing because Czechs and the Slovaks were represented jointly. Source: Vodvarka, 1993 (from 1880 to 1991); Census of Population, Household and Dwelings 2001 and 2011. Croatian Bureau of Statistics, Zagreb.

ber reached its peak in 1921 with 32,376 inhabitants (Agičić, 2000) (Figure 1). After that there was a continuous decline in the Czech population. According to Pepeonik (1967), this was partly due to the fact that people moved back to Czechoslovakia after the First and Second World War, and some emigrated to America, but the main reason for a drastic drop in numbers of the Czech population after the World War II was assimilation with the Croatian population, precipitated by mixed marriages.

In the last population census from 2011 only 9,641 Czechs in Croatia were registered. This means that from 1948 until 2011 their share decreased by $67 \%$, from almost 29,000 to less than 10,000. In those 63 years their numbers in the total population in Croatia dwindled down from $0.7 \%$ to mere $0.2 \%$. There are various causes for such regression among Czechs. According to Nejašmić (1990), this can be attributed to rural exodus and depopulation in Croatia, which also affected villages with larger or smaller Czech popula- tions. Natural change in the Czech population from the mid-196os until today has been negative, deaths outnumbering live births. Population ageing, pronounced among Czechs, has also contributed to their declining numbers. In the 2011 census the median age of the Czech population was 9.5 years higher than the Croatian average (42.0). Also, in view of the ethnic change in the "Czech villages" from 1971 until 1981, Nejašmić (1990, p. 36) claims that "the Czech population was reduced in part because a major percentage among them declared themselves as Yugoslavs".

As far as territorial distribution of Czechs is concerned, according to the latest census 2011, over 90\% of them live in continental Croatia. Their greatest concentration is in central Slavonia (between the Sava and Danube rivers), in the outlying areas of four Croatian counties (Požeško-slavonska, Bjelovarsko-bilogorska, Sisačko-moslavačka, Virovitičko-podravska), where over two thirds of all Czechs in Croatia are concentrated.

\section{Theoretical framework and previous research}

The level of interethnic marriages in a country is contingent on a number of factors. Kalmijn (1998) stated that marriage patterns result from both preference and opportunity. "Opportunity to marry within the group depends on many factors, such as residential segregation, the composition of local marriage markets, group size and so on" (Kalmijn, 1998, p. 397). In the preferences of marriage candidates, several kinds of resources play a role, "but sociologists have mostly focused on socio-economic and cultural resources" (Kalmijn, 1998, p. 398). 
Ethnic composition of the territory is the first factor that affects the number and percentage of interethnic marriages, especially those within a settlement. The greater the number of nationalities/ethnic groups that live in the same space, the greater the possibility that the number of interethnic marriages will be higher (Garrido \& Checa Olmos, 2014; Hwang at al. 1997; Lievens 1998). Size of ethnic groups is an important factor that defines ethic marriages (Kalmijn \& van Tubergen, 2006). This means that the percentage of interethnic marriages is mathematically predetermined by group size (Besanceney, 1965; Rosenfeld, 2002, Lanzieri, 2011). Or, according to Blau (1977) and RodrìguezGarcia (2012), the proportion of group members intermarried is an inverse function of group size. It can thus be concluded that majority groups are "forced" to be more endogamous than minority groups. Regional distribution of groups is also important because "continuous settlement, border settlement or for example an enclave have a different impact on heterogamy" (Petrović, R., 1985, p. 10). "Continuous settlement, especially if in case of monolithic ethnic structure, reduces heterogamy, whereas border settlement, for example, is conducive to mixed marriages" (Petrović, R., 1985, p. 11). Duration of contact period or group authenticity shows how new immigrants differ from groups who have been living together for centuries in their attitude towards heterogamy. Their cultural similarities and differences should be taken into account here. Furtado and Trejo (2012, p. 3) stated that "new immigrants enter into marriages with domicile population more often than the groups who have been in the host country for several generations." The "domination" factor of the majority group can have a psychological effect. The majority group can be more tolerant and open when it comes to partner choice than the minority group since they do not suffer from "assimilation fear" (Mrđen, 2000a).

Sex ratio is another factor that has an impact on marriage patterns. This biological framework is important for marriages in general, including those ethnically heterogenous as well. It also implies supply and demand for men and women, which necessarily affects the like- lihood of marriage for each sex. Numerous authors (Qian 1997; Kalmijn 1998; Jacobs \& Labov 2002; Kalmijn \& van Tubergen 2006; Rodrìguez-Garcìa 2012) emphasize that men are in general more exogamous than women as a result of a clearly patriarchal social order. Soroko (2014) also notes an important gender aspect of interethnic marriages in the Russian Federation. In all ethnic groups he has studied, women are less likely than men to marry outside their nationality. In the territory of former Yugoslavia it has also been observed that women are generally more endogamous than men (Mrđen, 2010). Apart from gender structure, age structure is also important and may also affect intermarriage. Both of those structural factors follow from the size of a group. This is especially important in smaller communities that are demographically old, which bears upon reproduction and a skewed sex ratio. As far as the Czech population in Croatia is concerned, according to the 2011 census, their median age was 51.5 years, which means that Czechs are demographically younger than Serbs, Hungarians and Slovenes and older than Croats and Slovaks. A quarter of the Czech population was aged 65 or more. The percentage of old population is higher among women than among men: the ratio is $30 \%$ to $20 \%$.

As far as cultural characteristics are concerned, "preferences for cultural similarity have been addressed most extensively in the social psychological literature on personal attraction" (Kalmijn, 1998, p. 399). In the territory of former Yugoslavia the most important cultural characteristics cover language, religion and historical background, and these are especially significant in terms of heterogamy and ethnic relations in general (Petrović, R., 1985; Botev, 1994; Smits, 2010). Socio-economic characteristics, many sociologists believe, play an important role in choosing a spouse. Partners are often similar in terms of age, level of education and social status (Smits, 1996). Furtado and Trejo (2012) also suggest that people with similar economic status are likely to be attracted to each other. Petrović, R. (1967) states, that most exogamous marriages take part in the same social group/category, with significantly greater frequency among men than among women.

\section{Data source and applied methods}

This article will provide a quantitative analysis of interethnic marriages in Croatia according to nationality, with special consideration of interethnic marriages among Czechs. The analysis is based on annual vital statistics for the period of 45 years (1970-2015) published by the Yugoslav Federal Statistical Office up until 1990, and after that according to the data provided by the Croatian Bureau of Statistics. This data is limited only to cross-classifications of the marriages by ethnicity of the spouses. The data on ethnic marriages according to age, education, occupation and rural and urban population were not published in the national statistics in former Yugoslavia nor are they being published in newly formed states and will be excluded from this article. As far as the data are concerned, it is important to note that, no data were published for Albanians, Roma and 
Bosniaks for 1970 either, nor for the period 1997-2000, and for Yugoslavs do no records exist since $1992^{4}$.

The article also tackles the analysis of interethnic marriage according to sex in order to establish whether there are gender differences between nationalities. For the purposes of this analysis only those nationalities were taken into consideration whose share in the total population in Croatia for 2011 was over 0.1\% (Croats, Albanians, Bosniaks, Czechs, Hungarians, Italians, Serbs, Slovaks and Yugoslavs) (Table 1). When interethnic marriage structure for the Czech population was considered, in order to establish which nationalities were dominant in those marriages into which Czechs entered outside their group, the nationalities chosen were those with which Czechs entered into over 100 marriages in the period between 1970 and 2015 (Croats, Serbs, Hungarians and people who declared themselves as Yugoslavs ${ }^{5}$ ) and Slovaks. ${ }^{6}$ The goal was to see whether the change to the status and rights of national minorities, brought about by the political climate after 1990, affected their direct relations with the majority group, and also to explore whether there was an increase in endogamy and any change in the ethnic structure of mixed marriages.

The article contains the most general measure (proportion/rate), which allows description of interethnic marriages, in general and according to sex, as well as interethnic marriage composition. The percentage of intermarrying couples is derived from the following table format:

\begin{tabular}{lccc}
\hline \multirow{2}{*}{ Males } & \multicolumn{2}{c}{ Females } & \multirow{2}{*}{$\begin{array}{c}\text { Total } \\
\text { married }\end{array}$} \\
\cline { 2 - 3 } & Nationality A & Nationality B & \\
\hline Nationality A & $\mathrm{C}_{\mathrm{AA}}$ & $\mathrm{C}_{\mathrm{BA}}$ & $\mathrm{MA}$ \\
Nationality B & $\mathrm{C}_{\mathrm{AB}}$ & $\mathrm{C}_{\mathrm{BB}}$ & $\mathrm{MB}$ \\
Total married & $\mathrm{F}_{\mathrm{A}}$ & $\mathrm{F}_{\mathrm{B}}$ & $\mathrm{N}$ \\
\hline
\end{tabular}

Where $C_{A A}$ is a marriage between wife and husband of the same nationality $(A) ; C_{B A}$ is a marriage between wife of nationality $B$ and husband of nationality $A_{;} C_{A B}$ is a marriage between wife of nationality $A$ and husband of nationality $B ; C_{B B}$ is a marriage between husband and wife of the same nationality (B); $M_{A}$ and $M_{B}$ are the total marriages among men of nationality $A$ and nationality $\mathrm{B} ; \mathrm{F}_{\mathrm{A}}$ and $\mathrm{F}_{\mathrm{B}}$ are the total marriages among women of nationality $A$ and nationality $B ; N$ is the total of all marriages. Source: According to Kalmijn (1998) and Lanzieri (2011).

4 In tables with endogamy findings for the five-year periods stated in the text, the data referring to Yugoslavs for the period 1990-1999 cover only two years, 1990 and 1991.

5 Yugoslav is the official name employed in the territory of former Yugoslavia to designate members of various ethnic groups who used this term in official population censuses and can be classified as ethnically uncommitted category.

6 Although Czechs entered into only 22 marriages with Slovaks during the period in question, their interethnic marriages will also be analyzed since these nationalities used to live in the same state and had settled in Croatia at the same time.
The percentage of A-type couples intermarrying is calculated from this formula:

$$
\left(\mathrm{C}_{\mathrm{BA}}+\mathrm{C}_{\mathrm{AB}}\right) /\left(\mathrm{C}_{\mathrm{BA}}+\mathrm{C}_{\mathrm{AB}}+\mathrm{C}_{\mathrm{AA}}\right)
$$

while the percentage of A-type persons intermarrying for males is $\mathrm{C}_{\mathrm{BA}} / \mathrm{M}_{\mathrm{A}}$ and for females is $\mathrm{C}_{\mathrm{AB}} / \mathrm{F}_{\mathrm{A}}$ (Kalmijn 1998, p. 405).

"This simple statistical method is easy to compute and interpret, but provides little information about the strength of endogamy/exogamy because it lacks a reference point and has many limitations" (Rosenfeld, 2002, 156). Its main drawback is that it does not take into consideration group size and it is less useful for comparison purposes because "when selection is random, small groups are less likely to marry within their group than large groups" (Kalmijn, 1998, p. 405). This is why the odds ratio method will be employed here.

The odds ratio (OR) for endogamy is a better measure of general assimilation than the percent exogamy (Rosenfeld, 2002; Kalmijn, 1998). Odds ratios are useful for comparing endogamy across groups because "they are independent of the relative sizes of the groups in the marriage table" (Kalmijn, 1998, p. 405). So the odds ratio will be employed to determine the level of endogamy for mentioned nationalities in Croatia and will also be applied in analyzing the structure of interethnic marriages between Czechs and other nationalities.

The odds ratio (OR) is calculated as follows (Kalmijn, 1998, p. 405):

$$
\begin{aligned}
& \text { OR }=\left(\mathrm{C}_{\mathrm{AA}} / \mathrm{C}_{\mathrm{BA}}\right) /\left(\mathrm{C}_{\mathrm{AB}} / \mathrm{C}_{\mathrm{BB}}\right) \\
& \text { or }\left(\mathrm{C}_{\mathrm{AA}} \cdot \mathrm{C}_{\mathrm{BB}}\right) /\left(\mathrm{C}_{\mathrm{BA}} \cdot \mathrm{C}_{\mathrm{AB}}\right)
\end{aligned}
$$

The natural logarithm of the odds ratio is calculated as follows:

$$
\ln (O R)=\sqrt{\frac{1}{C_{A A}}+\frac{1}{C_{B A}}+\frac{1}{C_{A B}}+\frac{1}{C_{B B}}}
$$

Log-odds ratios greater than zero (which correspond to odds ratio greater than 1), represent positive associations. Negative log-odds ratios indicate negative associations (Rosenfeld, 2001). 


\section{Results}

\section{The degree of intermarriage in Croatia}

The frequency of endogamous marriages in Croatia declined substantially over the course of thirty years, from $85 \%$ in 1970 to $81 \%$ in 1990 , when the endogamy rate was at its lowest (Figure 2). After 1990 the percentage of endogamous marriages increased significantly - in only three years it reached over 90\% in 1993 . The level of endogamous marriages remained as high in the following years as well (around 92\%).

The reason for the significant increase of endogamous marriages is the change in ethnic structure, brought about primarily by the war in the 1990 o (Table 1). The share of Croats in the total population rose, whereas the share of the second largest ethnic group

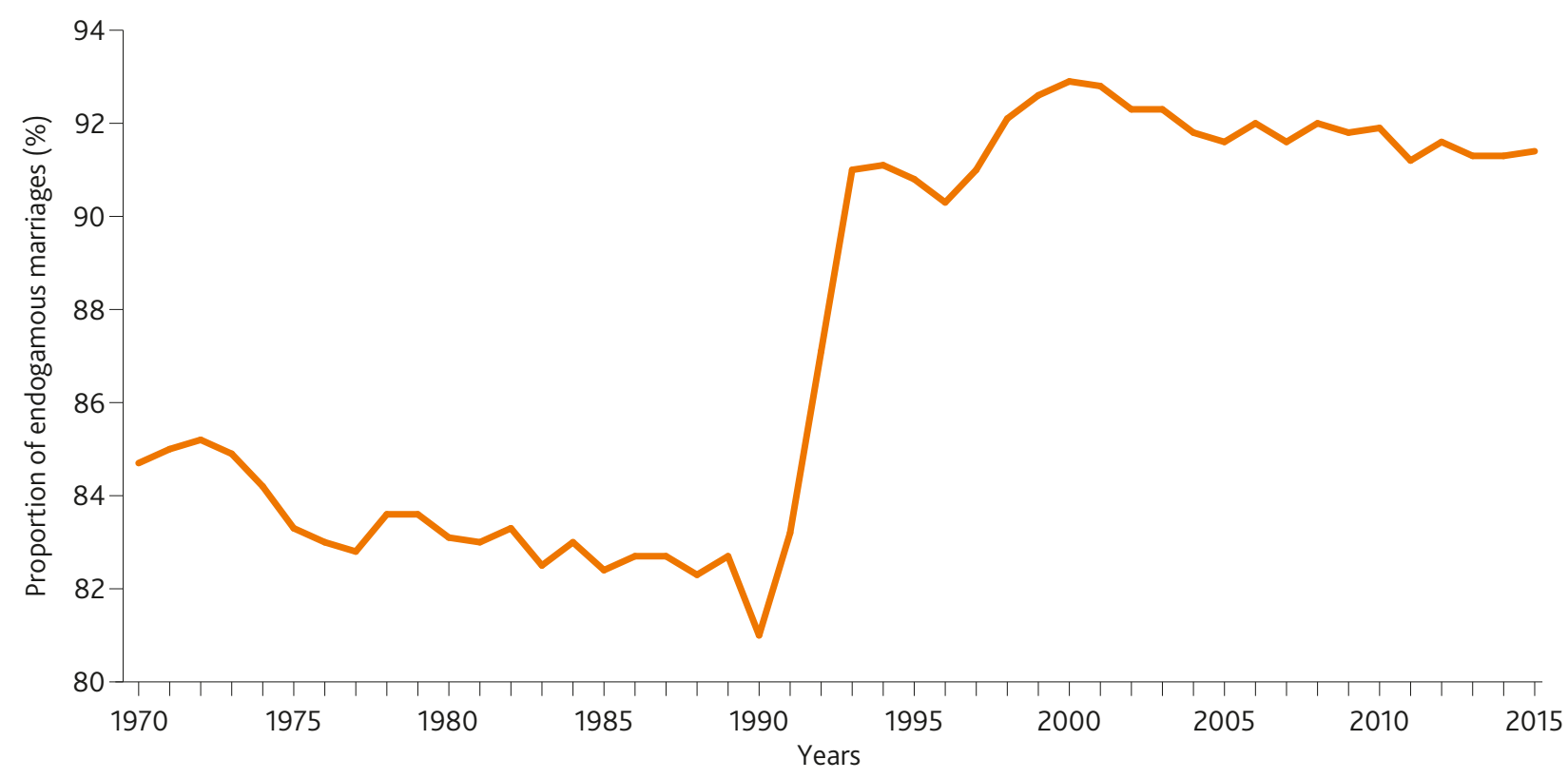

Figure 2. Proportion (\%) of endogamous marriages in the total number of marriages in Croatia, 1970-2015

Source: Calculated by authors based on data published in Demografska statistika from 1970 to 1990, Tab. Marriages by nationality of women and brides, Federal Statistical Office, Belgrade, and on Data set 6-1-4 from 1991 to 2015, Croatian Bureau of Statistics, Zagreb.

Table 1. Population by ethnicity according to censuses in Croatia, 1971-2011

\begin{tabular}{|c|c|c|c|c|c|c|c|c|c|c|}
\hline \multirow{2}{*}{ Nationality } & \multicolumn{5}{|c|}{ Number of population } & \multicolumn{5}{|c|}{ Percentage distribution } \\
\hline & 1971 & 1981 & 1991 & 2001 & 2011 & 1971 & 1981 & 1991 & 2001 & 2011 \\
\hline Albanians & 4175 & 6006 & 12032 & 15082 & 17513 & 0.1 & 0.1 & 0.3 & 0.3 & 0.4 \\
\hline Bosniaks* & 18457 & 23740 & 43469 & 20755 & 31479 & 0.4 & 0.5 & 0.9 & 0.5 & 0.7 \\
\hline Croats & 3513647 & 3454661 & 3736356 & 3977171 & 3874321 & 79.4 & 75.1 & 78.1 & 89.6 & 90.4 \\
\hline Czech & 19001 & 15061 & 13086 & 10510 & 9641 & 0.4 & 0.3 & 0.3 & 0.2 & 0.2 \\
\hline Hungarians & 35488 & 25439 & 22355 & 16595 & 14048 & 0.8 & 0.6 & 0.5 & 0.4 & 0.3 \\
\hline Italians & 17433 & 11661 & 21303 & 19636 & 17807 & 0.4 & 0.3 & 0.5 & 0.4 & 0.4 \\
\hline Roma & 1257 & 3858 & 6695 & 9463 & 16975 & 0.0 & 0.1 & 0.1 & 0.2 & 0.4 \\
\hline Serbs & 626789 & 531502 & 581663 & 201631 & 186633 & 14.2 & 11.6 & 12.2 & 4.5 & 4.4 \\
\hline Slovaks & 6482 & 6533 & 5606 & 4712 & 4753 & 0.1 & 0.1 & 0.1 & 0.1 & 0.1 \\
\hline Yugoslavs & 84118 & 379057 & 106041 & - & - & 1.9 & 8.2 & 2.2 & - & - \\
\hline Others** & 99374 & 143951 & 235659 & 161905 & 111719 & 2.2 & 3.1 & 4.8 & 3.8 & 2.7 \\
\hline Total & 4426221 & 4601469 & 4784265 & 4437460 & 4284889 & 100.0 & 100.0 & 100.0 & 100.0 & 100.0 \\
\hline
\end{tabular}

Notes: *Before 2011 Bosniaks used to declare themselves as Muslims in terms of nationality; **Comprises other nationalities (Austrians, Bulgarians, Montenegrins, Macedonians, Germans, Poles, Romanians, Russians, Ruthenians, Slovenians, Turks, Ukrainians, Vlachs, Jews) and persons who declared regional affiliation, religion, ethnically uncommitted, and unknown ethnicity. Since 2001 Yugoslavs and Muslims have been included in this category.

Source: Statistical Yearbook of the Republic of Croatia 2001; Census of Population, Households and Dwellings, 2011. Croatian Bureau of Statistics, Zagreb. 
(Serbs) and most other nationalities was reduced. In addition, deteriorated ethnic relations resulted in increasing the closure of the group.

If we consider the share of endogamous marriages across nationalities (Table 2), we can distinguish three groups. The highest level of endogamy was registered among Croats, the largest group: from 1970 until 1990 in a little over $80 \%$ of marriages were endogamous, rising to over $90 \%$ since the 1990s. A high level of endogamy was also registered among Roma, an ethnic group whose share in the total Croatian population is $0.4 \%$. The percentage of endogamous marriages in this group varied between $65 \%$ and $75 \%$ with noticeable periodical oscillations.
Among Bosniaks the level of endogamy held at steady $30 \%$ throughout the entire observation period.

The third group, comprised of Czechs, Slovaks, Hungarians and Italians, typically displays the lowest level of endogamy. Until 1990 the percentage of endogamous marriages among the first three nationalities was $20 \%$, sinking down to $15 \%$ after 1990 . The lowest percentage of endogamy in this group was observed among the Italians: around $10 \%$ for the entire period.

The percentage-based results of endogamy analysis show that the highest level of endogamous marriages was registered among Croats. Also, very high endogamy is characteristic of the Roma population. With them we should mention the Albanians and Bosnians

Table 2. Proportion (\%) of endogamous marriages in total number of marriages by ethnic groups and by gender in Croatia, 1970-2015

\begin{tabular}{|c|c|c|c|c|c|c|c|c|c|c|c|}
\hline Period & Marriages & Albanians & Bosni. & Croats & Czechs & Hungar. & Italians & Roma & Serbs & Slovaks & Yugoslavs \\
\hline \multirow{3}{*}{$\begin{array}{l}1970- \\
1979\end{array}$} & Total & 25.2 & 30.1 & 83.1 & 21.3 & 22.8 & 10.1 & 75.2 & 53.6 & 18.2 & 51.2 \\
\hline & Men & 28.9 & 58.3 & 90.3 & 37.6 & 39.7 & 17.1 & 80.6 & 69.4 & 32.4 & 65.9 \\
\hline & Women & 66.3 & 32.0 & 91.3 & 33.0 & 34.8 & 19.9 & 91.7 & 70.1 & 29.3 & 69.8 \\
\hline \multirow{3}{*}{$\begin{array}{l}1980- \\
1989\end{array}$} & Total & 34.4 & 32.2 & 82.1 & 17.7 & 21.9 & 9.3 & 74.5 & 49.8 & 27.0 & 53.6 \\
\hline & Men & 45.4 & 45.8 & 89.5 & 33.7 & 39.2 & 15.2 & 85.2 & 65.0 & 24.0 & 72.7 \\
\hline & Women & 68.0 & 51.4 & 90.7 & 27.2 & 33.2 & 19.1 & 85.5 & 68.1 & 28.9 & 67.0 \\
\hline \multirow{3}{*}{$\begin{array}{l}1990- \\
1999\end{array}$} & Total & 40.4 & 29.0 & 89.5 & 17.6 & 15.9 & 11.8 & 69.4 & 41.0 & 10.2 & 49.9 \\
\hline & Men & 48.1 & 32.1 & 94.7 & 31.1 & 28.4 & 16.1 & 82.1 & 58.7 & 18.2 & 72.6 \\
\hline & Women & 71.5 & 56.1 & 94.2 & 18.8 & 26.4 & 30.4 & 81.7 & 57.6 & 15.2 & 60.9 \\
\hline \multirow{3}{*}{$\begin{array}{l}2000- \\
2009\end{array}$} & Total & 48.6 & 33.9 & 92.4 & 11.1 & 16.0 & 8.2 & 70.8 & 38.9 & 12.6 & - \\
\hline & Men & 63.2 & 27.8 & 95.0 & 22.2 & 32.0 & 15.9 & 80.5 & 56.7 & 30.7 & - \\
\hline & Women & 67.8 & 68.1 & 97.1 & 18.1 & 24.3 & 14.6 & 85.5 & 55.3 & 17.7 & - \\
\hline \multirow{3}{*}{$\begin{array}{l}2010- \\
2015\end{array}$} & Total & 41.5 & 31.5 & 91.8 & 11.7 & 13.1 & 8.4 & 66.0 & 31.5 & 6.5 & - \\
\hline & Men & 55.2 & 20.5 & 94.4 & 22.4 & 25.2 & 15.5 & 80.7 & 48.9 & 15.4 & - \\
\hline & Women & 62.6 & 68.0 & 97.0 & 19.6 & 21.4 & 15.6 & 78.3 & 47.0 & 10.1 & - \\
\hline \multirow{3}{*}{$\begin{array}{l}1970- \\
2015\end{array}$} & Total & 40.5 & 31.1 & 86.8 & 17.8 & 20.4 & 9.8 & 70.6 & 49.6 & 16.8 & 52.7 \\
\hline & Men & 50.5 & 42.0 & 92.4 & 32.7 & 36.7 & 16.2 & 81.9 & 65.8 & 26.8 & 71.0 \\
\hline & Women & 67.2 & 52.5 & 93.5 & 28.1 & 31.5 & 20.1 & 83.6 & 66.9 & 22.4 & 67.1 \\
\hline
\end{tabular}

Source: Calculated by authors based on data published in Demografska statistika from 1970 to 1990, Tab. Marriages by nationality of women and brides, Federal Statistical Office, Belgrade, and on Data set 6-1-4 from 1991 to 2015, Croatian Bureau of Statistics, Zagreb.

In the other group represented by Serbs, Yugoslavs, Albanians and Bosniaks the level of endogamy is between $25 \%$ and $50 \%$. The highest percentage (around $50 \%$ ) was characteristic of Serbs and Yugoslav until 1990. After that the ratio of endogamous marriages in these two groups suddenly plummeted, which is associated with their decrease in the total population in Croatia. Also, due to the deterioration of ethnic relations, especially Serbs and Yugoslavs with Croats. On the other hand, the level of endogamous marriages among Albanians has been increasing ever since the 1970s. With the exception of the last observation period, the increase was continuously: from $25 \%$ up to almost $50 \%$. characterized by higher endogamy in relation to other national minorities. It follows from the above that these high endogamy is contrary to the conclusions in the literature according to which the low proportion of endogamous marriages are characteristics of ethnic groups that are numerically small (Blau at al. 1982; Rosenfeld, 2002; Rodrìguez-Garcìa, 2012).

\section{Odds ratio analysis}

Earlier on it was stated in this article that the downside of percent endogamy was that it does not take into account group size and is not precise enough to allow comparison of endogamy by nationality. So we 
will apply another indicator for endogamy, the odds ratio, which has already been explained. The odds ratio results are not dependent on group size because the odds ratio considers not only the odds referring to marriage outside the origin group, but also marriage within the origin group, i. e. endogamous marriage.

The odds ratio results for the entire period show that, although the highest endogamy level is typical of Croats, their odds ratio for marrying within the origin group is the lowest (23.8) in comparison to other nationalities (Table 3) The odds that a Croatian man
Hungarians and Yugoslavs. Slovaks are also a part of this group, but only since 2010. In comparison to the listed nationalities, Italians are less endogamous, as in the percent endogamy. Despite significant increase in the odds ratio endogamy, especially in the 199os and the first decade of the 21st century, Serbs however are less endogamous than other national minorities. This means that the endogamy odds ratios for Serbs rose from only 36.5 (in 1970-1979) to 86.3 (in 1990-1999) and declined to 58.9 in the last period (in 2010-2015). For Czechs and Hungarians, as well as Serbs, a log odds

Table 3. Odds ratios (OR) of ethnic endogamy for ethnic groups in Croatia, 1970-2015

\begin{tabular}{|c|c|c|c|c|c|c|c|c|c|c|c|}
\hline Period & Odds Ratio & Alban. & Bosni. & Croats & Czechs & Hungar. & Ital. & Roma & Serbs & Slovaks & Yugo. \\
\hline \multirow{2}{*}{$\begin{array}{l}1970- \\
1979\end{array}$} & Endogamy OR & 1942.5 & 300.1 & 18.4 & 190.1 & 122.3 & 108.6 & 126326.9 & 36.5 & 439.7 & 290.43 \\
\hline & $\log (\mathrm{OR})$ & 7.57 & 5.70 & 2.91 & 5.25 & 4.81 & 4.69 & 11.75 & 3.60 & 8.09 & 5.67 \\
\hline \multirow{2}{*}{$\begin{array}{l}1980- \\
1989\end{array}$} & Endogamy OR & 1549.1 & 161.9 & 18.5 & 198.4 & 158.5 & 148.9 & 26129.3 & 35.3 & 1151.2 & 102.4 \\
\hline & $\log (\mathrm{OR})$ & 7.35 & 5.09 & 2.92 & 5.29 & 5.07 & 5.00 & 10.17 & 3.56 & 7.05 & 4.63 \\
\hline \multirow{2}{*}{$\begin{array}{l}1990- \\
1999\end{array}$} & Endogamy OR & 1347.1 & 114.8 & 28.3 & 268.7 & 194.2 & 123.4 & 16311.5 & 86.3 & 362.5 & 109.6 \\
\hline & $\log (O R)$ & 7.17 & 4.71 & 3.06 & 5.57 & 5.25 & 4.79 & 9.70 & 4.44 & 5.87 & 4.89 \\
\hline \multirow{2}{*}{$\begin{array}{l}2000- \\
2009\end{array}$} & Endogamy OR & 1308.7 & 523.0 & 39.3 & 143.9 & 186.1 & 80.6 & 10871.5 & 84.7 & 340.0 & - \\
\hline & $\log (\mathrm{OR})$ & 7.18 & 6.26 & 3.67 & 4.97 & 5.23 & 4.39 & 9.29 & 4.44 & 5.83 & - \\
\hline \multirow{2}{*}{$\begin{array}{l}2010- \\
2015\end{array}$} & Endogamy OR & 783.1 & 290.8 & 32.9 & 198.7 & 150.6 & 82.8 & 5218.4 & 58.9 & 187.0 & - \\
\hline & $\log (\mathrm{OR})$ & 6.66 & 5.67 & 3.49 & 5.29 & 5.01 & 4.42 & 8.56 & 4.08 & 5.23 & - \\
\hline \multirow{2}{*}{$\begin{array}{l}1970- \\
2015\end{array}$} & Endogamy OR & 1389.6 & 214.2 & 23.8 & 208.1 & 162.5 & 108.0 & 16597.4 & 52.7 & 499.8 & 152.6 \\
\hline & $\log (\mathrm{OR})$ & 7.23 & 5.36 & 3.13 & 5.33 & 5.09 & 4.68 & 9.72 & 3.96 & 6.21 & 5.04 \\
\hline
\end{tabular}

$p<0.0001$ (for all nationalities)

Source: Calculated by authors based on data as for Table 2 by using the MedCalc statistical software, www.medcalc.org/calc/relative_risk.phpT

will marry a Croatian woman are 23.8 higher than for a non-Croatian man to marry a Croatian woman. These odds were less than 20.0 before 1990, but afterwards the odds value doubled ${ }^{7}$. Regardless of the increased odds value, it follows that Croats, contrary to the percent endogamy results, are the least endogamous in comparison to other nationalities. The highest odds ratios of endogamy across the entire period had Roma, despite the fact that the odds values decreased from the first to the last period, from over 126,000 (or $\log$ OR 11.75) to a little over 5,000 ( $\log$ OR 8.56). I. e. in the 1970 s the odds ratio for Roma men marrying Roma women was 126,00o times higher than for non-Roma men, as opposed to a little over 5,000 in the period 2010-2015. Albanians also display high odds ratio endogamy, although the odds values dropped down to 783.1 (2010-2015) from over 1,900 (1970-1979), but still remain higher than for other nationalities (with the exception of Roma).

The endogamy value of around 200.0 across the observed period was registered among Bosniaks, Czechs,

7 From 1991 until 1999 endogamy increased significantly, from 18.4 odds ratio to 32.9 . ratio was the highest in the period of the war (19901990).

\section{Interethnic marriages among Czechs}

From 1970 until 2015 the members of the Czech population in Croatia entered into a total of 6,625 marriages, and 1,001 of those were endogamous marriages (for couples), i. e. marriages within the Czech group, which makes for $17.8 \%$ of the total number of marriages. Remaining 4,623 marriages or $82.2 \%$ of the total number were with a member of some of the nationalities living in Croatia (Figure 3).

The total number of marriages among Czechs was steadily declining since 1970 . Over the course of 45 years the number of marriages decreased by over four times, from 312 marriages in 1970 it dropped down to only 72 marriages in 2015. The decrease was continuous until the early 1990s, when the number of marriages dropped down to under 100 annually and remained at that level for the next ten years or so, after which a new decrease took place (Figure 3). In 2013 the number of marriages was only 46 , the lowest since 1970. At the same time, the share of endogamous marriages among Czechs in the total number of marriages 


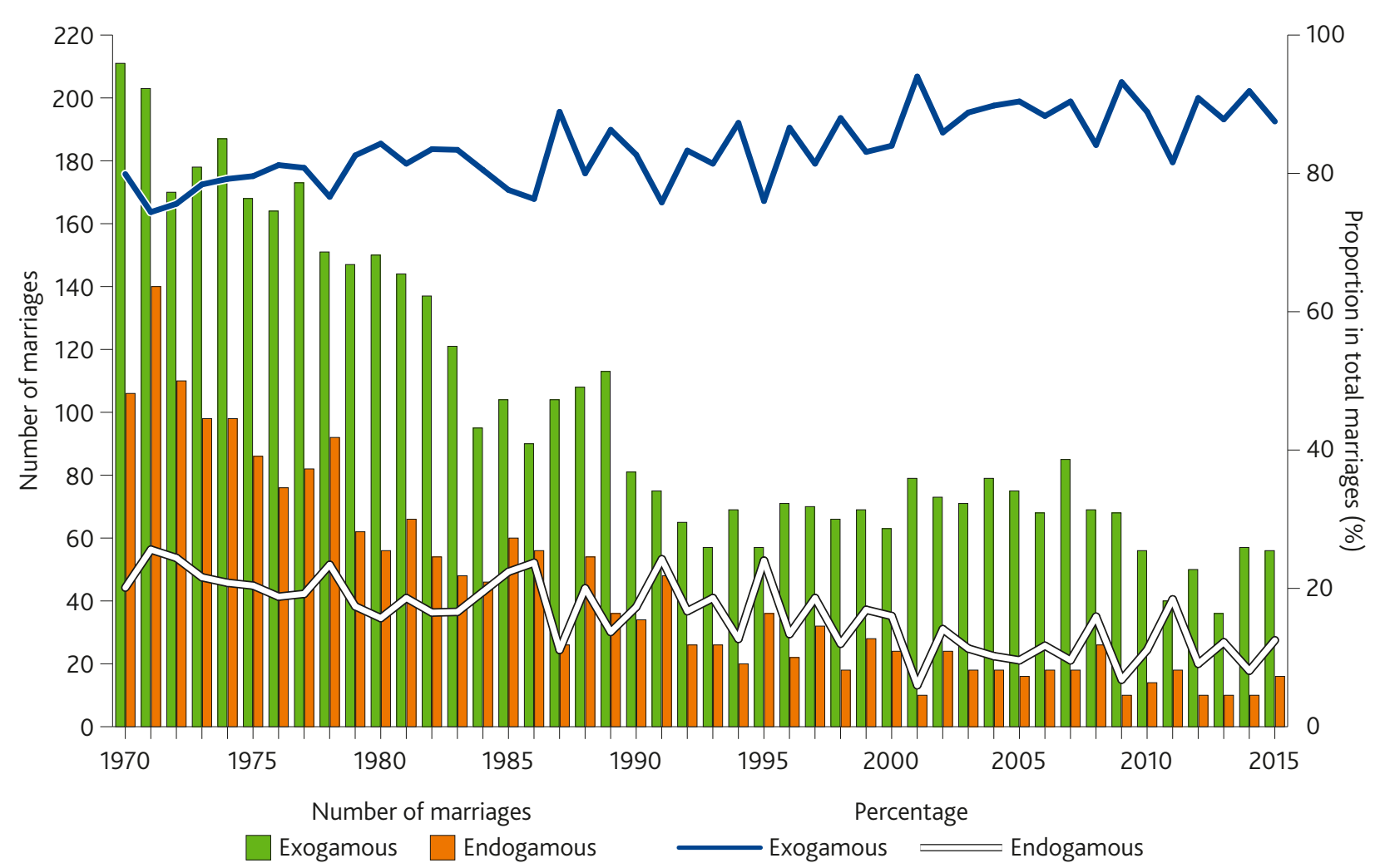

Figure 3. Number of endogamous and exogamous marriages among Czechs in Croatia, 1970-2015.

Source: Calculated by authors based on data published in Demografska statistika from 1970 to 1990, Tab. Marriages by nationality of women and brides, Federal Statistical Office, Belgrade, and on Data set 6-1-4 from 1991 to 2015, Croatian Bureau of Statistics, Zagreb.

was constantly dropping, from around 100 marriages in the early 1970 s to only around 10 marriages by the end of the observed period.

\section{Czech men more endogamous than Czech women}

In the period 1970-2015 the total number of marriages among Czech men was 3,058. Of those, 2,057 (or $67 \%$ ) marriages were outside the group and 1,001 with Czech women. In the same period the total number of marriages among Czech women was slightly higher (3,567). 2,566 (or $72 \%$ ) of those were with a partner from another ethnic background, and 1,001 with a partner from the same ethnic group.

In the early 1970 s the percentage of endogamous male and female marriages among Czechs was around $35 \%$ and after 2000 around 20\% (Figure 4). Although temporal dynamics of marriage rates by gender is symmetrical, the exogamy rates are somewhat higher among women than among men. In the period of 45 years the exogamy rates for men were higher than those for women during only six years. The greatest differences in exogamy between men and women were manifest in the 1980s, early 1990s and in 2008, whereas the share of endogamous marriages among men reached its highest level of $48 \%$ in 1991.

Earlier in the text it was stated that in almost all communities exogamous marriages occurred more frequently among men than among women. In addi- tion to this, men who belong to ethnic minorities tend to enter into marriages outside their group more often than women (Kalmijn 2006, Rodriguez-Garcia 2012). The trend for interethnic marriages of Czech men and women in Croatia is in contrast to this conclusion. Although temporal dynamics of endogamous marriage rates by gender is symmetrical, the endogamy rates are somewhat higher among men than among women. If we compare gender differences in ethnic endogamy among Czechs with other national minorities in Croatia (Table 2), it follows that, just like Czech women, Hungarian, Slovak, Bosniak and Yugoslav women were entering into marriage outside their group more often than men across the entire observation period. Among Croats, Serbs, Albanians, Italians and Roma men are more exogamous than women. Albanians stand apart as the nationality group that has displayed the greatest difference between the rates of endogamy for men and women.

\section{Croats the most frequent spouse in Czech marriages} Throughout the period from 1970 until 2015 Czechs mostly entered into marriages with Croats, which makes for 3,648 or $79 \%$ of all exogamous Czech marriages. This percentage was significantly lower for other nationalities: most other marriages were with Serbs (431 marriages or $9.3 \%$ of the total number of exogamous marriages among Czechs), and less with other 


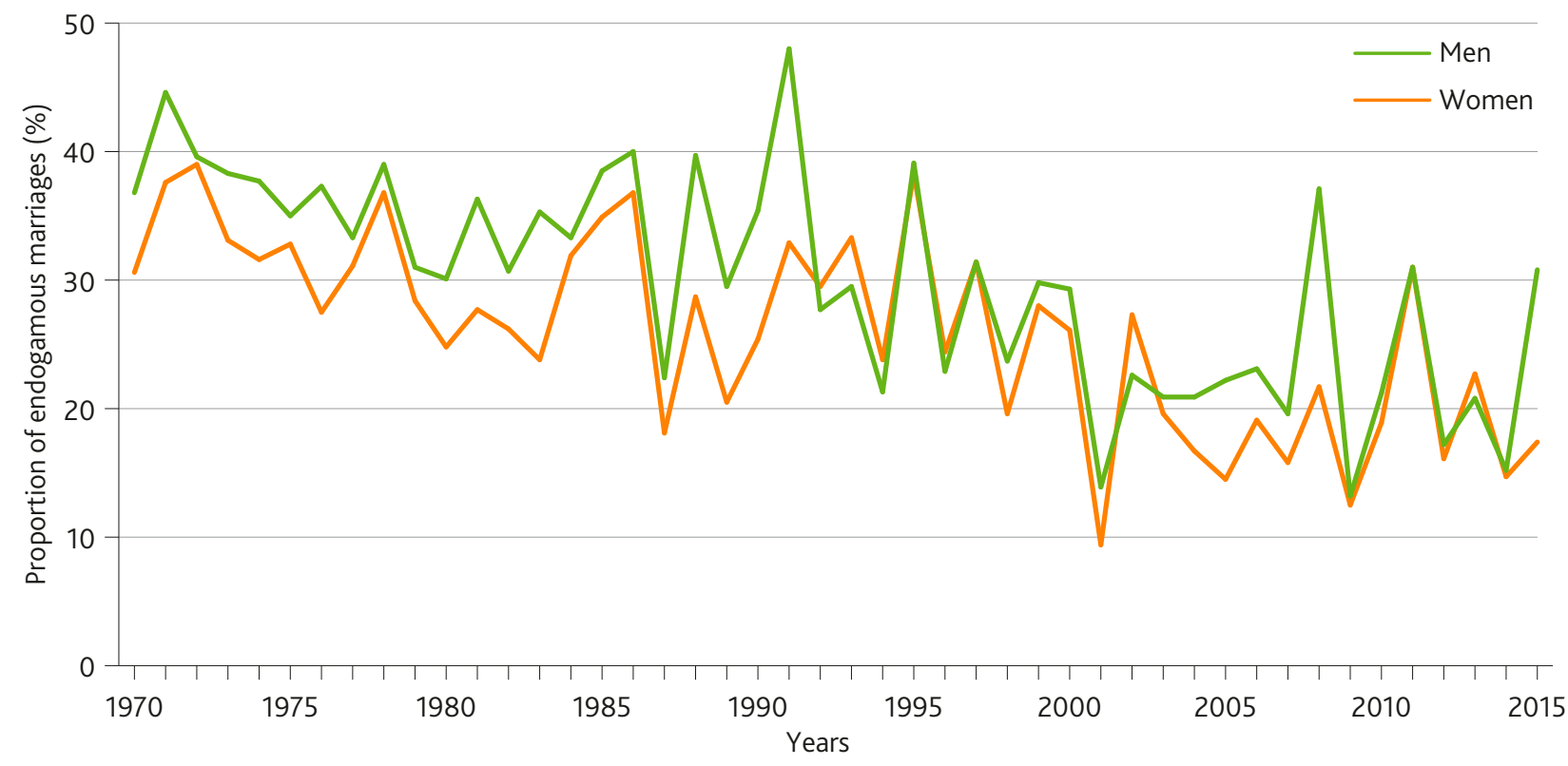

Figure 4. Proportion (\%) of endogamous marriages among Czechs by sex in Croatia 1970-2015

Source: Calculated by authors based on data published in Demografska statistika from 1970 to 1990, Tab. Marriages by nationality of women and brides, Federal Statistical Office, Belgrade, and on Data set 6-1-4 from 1991 to 2015, Croatian Bureau of Statistics, Zagreb.

nationalities, where the especially low rate of marriages with Slovaks stands out (only 22 marriages across the entire observation period). ${ }^{8}$

Although the number of marriages between Czechs and Slovaks is very low, it follows that until 1990 Slovaks were the group most open to marriages with Czechs (Table 4, column 1). Out of the total num- the 1990s Hungarians have been very open towards Czechs, more so than Slovaks. Across the entire observation period Czechs were a partner in $1.3 \%$ of exogamous Hungarian marriages. On the other hand, out of the total number of Czechs who entered into marriage, only $0.4 \%$ of them married a Slovak man or woman across the entire observation period (Table 4,

Table 4. Proportion (\%) of mixed marriages of Czechs with other nationalities in Croatia, 1970-2015

\begin{tabular}{|c|c|c|c|c|c|c|c|c|c|c|}
\hline \multirow[t]{2}{*}{ Period } & \multicolumn{2}{|c|}{ Croats } & \multicolumn{2}{|c|}{ Hungarians } & \multicolumn{2}{|c|}{ Serbs } & \multicolumn{2}{|c|}{ Slovaks } & \multicolumn{2}{|c|}{ Yougoslaves } \\
\hline & 1 & 2 & 1 & 2 & 1 & 2 & 1 & 2 & 1 & 2 \\
\hline 1971-1979 & 0.4 & 59.2 & 1.6 & 2.8 & 0.3 & 9.7 & 1.6 & 0.6 & 0.5 & 2.1 \\
\hline 1980-1989 & 0.3 & 58.6 & 1.2 & 2.1 & 0.2 & 8.6 & 2.1 & 0.5 & 0.4 & 7.1 \\
\hline 1990-1999 & 0.3 & 69.7 & 1.5 & 1.8 & 0.5 & 4.9 & 0.3 & 0.1 & 0.2 & 1.9 \\
\hline 2000-2009 & 0.3 & 80.2 & 0.5 & 0.6 & 0.4 & 4.8 & 0.4 & 0.3 & - & - \\
\hline $2010-2015$ & 0.3 & 79.6 & 1.0 & 1.5 & 0.3 & 4.2 & 0.5 & 0.3 & - & - \\
\hline $1970-2015$ & 0.3 & 64.9 & 1.3 & 2.1 & 0.3 & 7.7 & 1.1 & 0.4 & 0.4 & 3.7 \\
\hline
\end{tabular}

Notes:

$1=$ Proportion (\%) of mixed marriages of Czechs with other nationalities in total marriage of other nationalities

2=Proportion (\%) of mixed marriages of Czechs and other nationalities in total Czech marriage

Source: Calculated by authors based on data as for Table 2.

ber of Slovaks who entered into marriage in the period 1970-1979, 1.6\% of them married a member of the Czech group, and in the period 1980-1989 it was $2.1 \%$ or $1.1 \%$ in the entire observation period. Also, since

8 With other nationalities in Croatia (Montenegrins, Bosniaks, Slovenians, Albanians, Italians, Ruthenians and "others", including persons who declared regional affiliation, persons who remained ethnically uncommitted and persons whose ethnicity is unknown), Czechs entered into 246 marriages or $5.3 \%$ of the total number of Czech marriages. column 2). At the same time, the rate of Czechs who entered into marriage with a Hungarian man or woman was significantly higher (2.1\%).

In mixed Czech marriages Croats were the most common partner to Czechs across the entire observation period. In the first observation period Croats were a partner in $59.2 \%$ and after 2000 in about $80 \%$ of the total number of mixed Czech marriages (Table 4, column 2). But if we look at the percentage of Czechs in Croatian marriages, it follows that Croats are the 
Table 5. Odds ratio for Czechs with other nationalities in Croatia, 1970-2015

\begin{tabular}{|l|l|c|c|c|c|c|c|}
\hline Period & Odds Ratio & Croats & Hungarians & Serbs & Slovaks & Yugoslavs & Others \\
\hline \multirow{3}{*}{$1970-1979$} & Endogamy OR & 284.7 & 450.2 & 1582.6 & 1853.8 & 4135.6 & 703.8 \\
\cline { 2 - 8 } & Log (OR) & 5.65 & 6.11 & 7.37 & 7.52 & 8.33 & 6.56 \\
\hline \multirow{3}{*}{$1980-1989$} & Endogamy OR & 320.9 & 615.9 & 1855.6 & 2656.4 & 1306.3 & 1419.1 \\
\cline { 2 - 8 } & Log (OR) & 5.77 & 6.42 & 7.53 & 7.88 & 7.17 & 7.26 \\
\hline \multirow{2}{*}{$2000-2009$} & Endogamy OR & 342.68 & 455.3 & 1814.2 & 6111.0 & 8617.8 & 4115.6 \\
\cline { 2 - 8 } & Log (OR) & 5.84 & 6.12 & 7.5 & 8.72 & 9.06 & 8.32 \\
\hline \multirow{2}{*}{$2010-2015$} & Lndogamy OR & 167.5 & 2548.0 & 964.4 & 4282.2 & - & 4937.4 \\
\cline { 2 - 8 } & Endogamy OR & 230.23 & 435.5 & 1271.6 & 658.3 & - & 8.50 \\
\cline { 2 - 8 } & Log (OR) & 5.44 & 6.08 & 7.15 & 6.49 & & 12675.0 \\
\hline \multirow{2}{*}{$1970-2015$} & Endogamy OR & 294.76 & 551.5 & 1628.0 & 3137.1 & 2737.8 & 2224.5 \\
\cline { 2 - 8 } & Log (OR) & 5.69 & 6.31 & 7.40 & 8.05 & 7.91 & 7.71 \\
\hline
\end{tabular}

$p<0.0001$ (for all nationalities)

Source: Calculated by authors based on data published in Demografska statistika from 1970 to 1990, Tab. Marriages by nationality of women and brides, Federal Statistical Office, Belgrade, and on Data set 6-1-4 from 1991 to 2015, Croatian Bureau of Statistics, Zagreb.

most closed group towards Czechs. In the 1970 o. $0.4 \%$ of the Croats who entered into marriage did so with a Czech woman or man, with a downward trend that resulted in only $0.2 \%$ in the last observation period or $0.3 \%$ across the entire period (1970-2015).

As far as Czech-Serbian marriages are concerned, out of the total number of Czechs who entered into marriage between 1970 and 2015, 7.7\% did so with a member of the Serbian nationality, Czech men slightly more often than Czech women. In the early 1970s this percentage was $9.7 \%$ and after 1990 less than $5 \%$. On the other hand, Serbs were a relatively closed group towards Czechs in their mixed marriages. Out of the total number of members of the Serbian nationality who entered into marriage during the period 19702015 , only $0.3 \%$ of them did so with a member of the Czech nationality (Table 4, column 1).

Persons who declared themselves as Yugoslavs were more represented in exogamous Czech marriages than Slovaks or Hungarians. In the 1980 s $7.1 \%$ of Czechs entered into marriage with persons who declared themselves as Yugoslavs and only 0.5\% did so with Slovaks or $1.2 \%$ with Hungarians. On the other hand, Yugoslavs were significantly less open towards marriages with Czechs than Slovaks or Hungarians.

Table 5 shows the the odds ratio results for endogamy between Czechs and other nationalities (Croats,
Serbs, Hungarians, Slovaks, Yugoslavs). The highest odds endogamy across the entire observation period was documented among Czechs and Slovaks. The odds ratio for the entire observation period was higher than 3,00o. This means the odds that a Czech man will marry a Czech woman were 3,0oo higher than for a Slovak man to marry a Czech woman. A high level of endogamy was also documented between Czechs and Serbs, Czechs and Yugoslavs or for some other nationalities living in Croatia.

On the other hand, the lowest level of endogamy was documented between Czechs and Croats. Across the entire observation period the odds that a Czech man will marry a Czech woman were 294.4 higher than for a Croat man to marry a Czech woman. It should be emphasized that the level of endogamy reached its peak during the 1990s (the odds were 342.7 ) and dropped afterwards. In addition to Croats, the endogamy in relation to other nationalities was also low for marriages between Czechs and Hungarians. Across the entire observation period the odds were 551.5, which is three times less than for Serb-Czech marriages or, for example, six times less than for Czech-Slovak or Czech-Yugoslav marriages. Czech marriages related to other nationalities in Croatia show a constant increase of endogamy, from a log odds ratio of 6.56 in the first period to 9.45 in the last.

\section{Discussion}

The main aim of this study was to analyze interethnic marriages in Croatia with special emphasis on interethnic marriages among Czechs. The analysis was carried out over a period of more than forty years
(1970-2015). In addition to descriptive analysis, based on interethnic marriage percentage, the odds ratio method was applied as well. 
The share of endogamous marriages in Croatia was continuously dropping from 1970 until 1990, holding at about $80 \%$. After 1990 there was a sudden surge of endogamy to over $90 \%$ of the total number of marriages. On one hand, the reason for this was the change in ethnic structure where the share of the majority nationality in the total population increased, whereas the share of national minorities in the total population declined. So Croats are, in terms of percentages, the most endogamous group. Because of their numbers, Croats have the least chance of finding a partner outside their group, which leads to a high level of endogamy. But if we take into account the results of the odds ratio method, it follows that Croats are the least endogamous in comparison to other nationalities. Also, Serbs display a lower level of the odds ratio endogamy in comparison to other national minorities. However, it should be pointed out that since 1990 the odds ratio endogamy among Serbs has doubled, despite the fact that the number of members of this nationality in the total Croatian population has dropped over three times since 1991. The reason for closing inside the group was not only its decreased share in the total population of Croatia, but also aggravated in terethnic relations, mostly with the majority nationality (Croats).

Czechs, Hungarians, Italians and Yugoslavs are characterized by a higher level of the odds ratio endogamy in comparison to Croats and Serbs, but still significantly lower in comparison to Albanians and Roma. By cross-referencing the percentage endogamy with the odds ratio endogamy among national minorities, we can see that Roma, along with Albanians, are the most endogamous group in Croatia, despite their small numbers in the total population. These are closed communities in which traditional values as well as affiliation with the Islamic cultural sphere ${ }^{9}$ affect the endogamy level.

Czechs are, along with Hungarians, Slovaks and Italians, a small group in terms of numbers, but are territorially concentrated. Over two thirds of Czechs in Croatia are characterized by compact population density in the central area between the rivers Sava and Drava and it can be surmised that such geographical distribution has an impact on a higher level of endogamous marriages, as the literature suggests. I. e. the groups concentrated in a certain area have a greater chance of marrying endogamously than the groups that are not (Kalmijn, 1998). However, it can be inferred from the analysis that geographic distribution did not affect attitudes towards interethnic marriage

9 According to the latest Croatian census, $55 \%$ of Albanians and $30 \%$ of Roma declared themselves as Muslims in terms of religious affiliation. because the share of marriages Czechs entered into within their own group was less than $18 \%$ across the observation period.

Period of coexistence with domicile groups is also one of the factors that have an impact on endogamy levels. Czechs settled in Croatia over 150 years ago. Despite the large number of interethnic marriages, they have managed to preserve their own language and culture until this day. However, it is important to point out that it remains unknown whether persons who enter into marriage and who declare themselves as Czechs, come from a family that is ethnically Czech or whether their parents had already entered into an interethnic marriage. For example, according to the census from 1981, almost 13 thousand people stated that their mother tongue was Czech and a little over 400 among them declared themselves as Croats in the nationality category. On the other hand, slightly over 3 thousand persons who declared themselves as Czechs (or 24\% of the total Czech population that numbered 15,061 in 1981) stated that their mother tongue was Croato-Serbian/Serbo-Croatian/Croatian/Serbian. ${ }^{10}$

As far as differences by gender and attitude towards exogamy are concerned, although the gap in intermarriage frequency is not as great, it follows that Czech men are more endogamous than Czech women. This runs contrary to many conclusions in the literature, according to which exogamy rates among men are higher than among women in almost all communities. Slovaks, Hungarians and Yugoslavs are characterized by the same marriage attitudes in terms of gender. In contrast, a higher level of endogamy has been documented among Serb, Italian and Bosniak and particularly Albanian and Roma women than among men. This is confirmed by an analysis from the literature according to which women are more endogamous than men because they are more frequently prevented from interreligious marriages (Kalmijn \& van Tubergen, 2006).

From the structure of interethnic marriages among Czechs it follows that the largest number of such marriages was with Croats, the dominant group. The share of Czech-Croat marriages has been constantly rising, which has caused a decline in marriages with other nationalities. Croats were more frequent partners in exogamous marriages of Czech women than Croat women in exogamous marriages of Czech men. Czechs entered into marriages with Slovaks the least although they are culturally closest to them in all maters apart from religion. According to the 2011 census, around $30 \%$ of Slovaks declared themselves as Protes-

10 This was a modality for answering the mother tongue question in the 1981 population census in Yugoslavia. 
tants in terms of religion, and $88 \%$ Czechs as Catholics. The reason for very few Czech-Slovak intermarriages is probably territorial distribution, i. e. territorial distance, and not Slovak religious affiliation. Czechs are concentrated in the central part of the Pannonian Basin for the most part, whereas Slovaks are in the east part of Croatia. In addition to this, there are almost twice as many Czechs than Slovaks in Croatia.

The fact that religious affiliation was not decisive for Czech-Slovak marriages is also evident in the share of Czech-Serbian marriages that is significantly higher. Unlike Slovaks, most Serbs live in the same areas as Czechs, which has made the contact between these two ethnic groups possible, regardless of their different religious affiliations (Czechs are Catholic, Serbs Orthodox). Also, there is less endogamy between Czechs and Hungarians than between Czechs and Slovaks, although these groups speak different languages. Furthermore, in the 1980s the percentage of marriages with persons who declared themselves as Yugoslavs was significant, outnumbering marriages with Slovaks or Hungarians. However, it is uncertain how many of the Czech-Yugoslav marriages are "homogamous", since the original ethnicity of the persons who declared themselves as Yugoslavs remains unknown.

On the other hand, if we consider the share of Czechs as partners in the total number of marriages of other nationalities, Croats emerge as the group most closed towards Czechs. Also, the number of Czechs who were partners in Serb exogamous marriages was small, smaller than in exogamous marriages among Hungarians and Slovaks.

From all points above, it can be concluded that cultural characteristics were not a decisive factor for Czechs in choosing a partner outside their group. More significant were the size and territorial distribution of other nationalities with which Czechs coexisted (Croats, Serbs, Hungarians, and Yugoslavs). The odds ratio results reveal that the ethnic distance between Czechs and Slovaks is greater than between Czechs and Croats, Czechs and Serbs or, for example, between Czechs and Yugoslavs. Furthermore, since the status of national minorities in Croatia changed after it became a sovereign state, there was a change in attitude of national minorities towards interethnic marriage. So from 1990 onwards the endogamy between Czechs and other nationalities has been higher than among Czechs and Croats. This can be explained by a reduced percentage of all nationalities (except the dominant Croat group) in the total population in Croatia, which affects supply and demand in the marriage market. The psychological factor of domination and, simultaneously, protection of the largest group from which a partner is chosen also plays an important role.

\section{Conclusion}

Since 1990 the share of endogamous marriages in Croatia has risen to over $90 \%$. The reason for this is the change in ethnic structure in Croatia after it declared independence. The percentage of Croats as the largest group increased, whereas the share of national minorities in the total population dropped. War and aggravated ethnic relations caused a change in the status of national minorities as well, which affected attitude towards interethnic marriage. According to the odds ratio method that considers group size, Croats are the least endogamous in comparison to other ethnic groups, which is the opposite of what the percentage endogamy results show. Czechs, Hungarians, Slovaks and Italians, despite being territorially concentrated, display a significantly lower level of endogamy than, for example, Albanians and Roma, and higher than Serbs who are the largest ethnic group. Differences between interethnic marriages by gender show that male endogamy among Czechs, Slovaks, Hungarians, Bosniaks and persons who declare themselves as $\mathrm{Yu}$ - goslavs is higher than female endogamy in the same group, which is not the case for other nationalities. As far as interethnic Czech marriages are concerned, Croats are the most frequent partner, although Croats represent the group that is most closed towards Czechs. The number of Czech-Slovak marriages has been very low across the entire observation period (only 22 marriages). These ethnic groups used to live together in the same states and settled in Croatia at almost the same time. Also, they have more cultural characteristics in common with each other than with other ethnic groups. So it follows that a small number of Czech-Slovak marriages can probably be attributed to geographic distribution. Both Czechs and Slovaks are territorially concentrated groups, but they are geographically distant, which leaves little opportunity for interethnic contacts. This indicates that territorial proximity and ethnic composition have a greater impact on ethnic structure of marriages than cultural characteristics of a nationality group. 


\section{References}

Agičić, D. (2000). Hrvatsko-češki odnosi na prijelazu iz 19. u 20. stoljeće [Croatian-Czech relations in transition from 19th to 2oth century]. Zagreb: IBIS grafika. (in Croatian)

Besanceney, P.H. (1965). On Reporting Rates of Intermarriage. American Journal of Sociology, 70(6), 717721. doi:10.1086/223966

Blau, P. (1977). Inequality and Heterogeneity: A Primitive Theory of Social Structure. New York, NY: The Free Press.

Blau, P., Blum, T.C., \& Schwartz, J.E. (1982). Heterogeneity and intermarriage. American Sociological Review, 47(1), 45-62. doi:10.2307/2095041

Botev, N. (1994). Where east meets west: Ethnic intermarriage in the former Yugoslavia, 1962 to 1989. American Sociological Review, 59(3), 461-480. doi: 10.2307/2095944

Bromlei, Y., \& Kashuba, M.S. (1982). Marriage and Family in the Yougoslav Nations. Moscow: Nauka. (in Russian)

Croatian Bureau of Statistics. (2001). Statistical Yearbook of the Republic of Croatia. Available at: http:// www.dzs.hr/.

Croatian Bureau of Statistics. (2001). Population by ethnicity, by towns/municipalities. In Census of Population, Households and Dwellings. Available at: http://www.dzs.hr/ (14. 11. 2017)

Croatian Bureau of Statistics. (2011). Population by ethnicity, by towns/municipalities. In Census of Population, Households and Dwellings. Available at: http://www.dzs.hr/ (14. 11. 2017)

Croatian Bureau of Statistics. Data set, Table 6-1-4, Marriages by nationality of women and brides, from 1991 to 2015. Zagreb: Croatian Bureau of Statistics.

Federal Bureau of Statistics. Demographic statistics from 1970 to 1990, Marriages by nationality of women and brides. Belgrade.

Dugački, V. (2013). Svoj svome. Češka i slovačka manjina u međuratnoj Jugoslaviji (1918-1941) [To your own. Czech and Slovak minorities in interwar Yugoslavia (1918-1941)]. Zagreb : IBIS grafika. (in Croatian)

Djurdjev, B., Bubalo-Živković, M., Ivkov-Džigurski, A., \& Ivanović, Lj. (2009). Majorities and Minorities in Former Yugoslav Countries at Turn of the $21^{\text {st }}$ Century. Geographica Pannonica, 13(4), 118-126.

Furtado, D. \& Trejo, S.J. (2012). Interethnic Marriages and their Economic Effects. IZA Discussion Papers 6399, Institute for the Study of Labor.

Garrido, A.A. \& Checa Olmos, J.C. (2014). The Marriage Market in Spain. Analysis of the Structure of Opportunity in Mixed Marriages. Sociologia - Slovak Sociological Review 46(3), 300-319.
Gorenburg, D.P. (2006). Rethinking Interethnic Marriage in the Soviet Union. Post-Soviet Affairs, 22, 145-165. doi: 10.2747/1060-586X.22.2.145

Herout, V. (2008). Kulturno-prosvjetni rad Čeha na prostoru Bjelovarsko-bilogorske županije [The Cultural and Educational Activity of the Czechs in the Area of the Bjelovar- Bilogora County]. Radovi Zavoda za znanstvenoistraživački i umjetnički rad u Bjelovaru, 2, 126-127. (in Croatian with English summary)

Horina, I. (2013). Výsledky sčítání lidu, Přehled kulturních, literárních a školních otázek [The results of the census list of cultural, literary and educational issues]. Jednota, 31, 5-13. (in Czech).

Hwang, S., Saenz, R., \& Aquirre, E.B. (1997). Structural and assimilationist explanations of Asian American intermarriage. Journal of Marriage and the Family 59(3), 758-772. doi:10.2307/353959

Jacobs, J. \& Labov, T. (2002). Gender differentials in intermarriage among sixteen race and ethnic groups. Sociological Forum 17(4), 621-646. doi:10.1023/a:1021029507937

Kalmijn, M. (1998). Intermarriage and homogamy: Causes, Patterns, Trends. Annual Review of Sociology, 24(1), 395-421. doi: 10.1146/annurev.soc.24.1.395

Kalmijn, M. \& Van Tubergen, F. (2006). Ethnic intermarriage in the Netherlands: confirmations and refutations of accepted insights. European Journal of Population, 22(4), 371-397. 371-397. doi:10.1007/ s10680-0o6-9105-3

Klopćić, V. (1992). Le droit des langues dans l'ex Yougoslavie. In H. Giordan (Ed.) Les minorités en Europe (pp. 328-329). Paris: Ed. Kimé.

Lachance, P. (1982). Intermarriage and French Cultural Persistence in Late Spanish and Early American New Orleans. Histoire sociale-Social History 15(28), 47-81.

Lanzieri, G. (2011). A Comparaison of Recent Trends of International Marriages and Divorces in European Countries. Paper for the IUSSP Seminar on Global Perspectives on Marriage and International Migration, Seoul, South Korea, 20-21 October. Available at: http://www.academia.edu/2565606/A_ comparison_of_recent_trends_of_international_ marriages_and_divorces_in_European_countries

Le Goff, J.M. \& Giudici, F. (2009). Transition to marriage in former Yugoslavia. Interethnic differences across cohorts. Facing massive violence and social change: Collective experiences in former Yugoslavia, 1-21, Lausanne.

Le Goff, J.M. \& Giudici, F. (2014). The Demise of Mixed Marriage? Ethnic Boundaries Between Families in Changing Societies. In D. Spini, G. Elcheroth, \& D. 
Corkalo Biruski (Eds.): War, Community and Social Change (pp. 63-84). Peace Psychology Book Series 17, Springer Science/Business Media.

Lievens, J. (1998). Interethnic marriage: bringing in the context through multilevel modeling. European Journal of Population, 14(2), 117-155. http://www.jstor. org/stable/20164026. doi: 10.1023/a:1006075325546

Matušek, J.(1996). Česi u Hrvatskoj [Czechs in Croatia]. Jednota, 210 p. (in Croatian)

Giles, W., Hyndman, J., \& Morokvašić-Müller, M. (2004). From pillars of Yugoslavism to target of violence. Interethnic marriages in the former Yugoslavia and thereafter. In W. Giles, J. Hyndman (Eds.), Sites of violence. Gender and conflict zones (pp. 134151). Berkeley: University of California Press. doi: 10.1525/california/9780520230729.003.0006

Mrđen, S. (2002). Narodnost u popisima. Promjenljiva i nestalna kategorija [Ethnicity in Censuses. Changeable and Inconstant Category]. Stanovništvo, 40(1-4), 77-103. (in Croatian, with English summary), doi:10.2298/stnvo201077m

Mrđen, S. (2010). Etnički miješani brakovi na prostoru bivše Jugoslavije, 1970-2005. godine [Ethnically Mixed Marriages in the Area of the Former Yugoslavia (1970-2005)]. Zbornik Matice srpske za društvene nauke, 131, 255-268. (in Serbian with English summary) doi:10.2298/zmsdn1031255m

Mrdjen, S. (1996). La mixité en ex-Yougoslavie. Intégration ou ségrégation des nationalités? Revue d'etudes comparatives Est-Ouest, 27(3), 103-144. www.persee.fr/issue/receo_0338-0599_1996_num_27_3. doi:10.3406/receo.1996.2801

Mrdjen, S. (2000a). Structures démographiques, nationalités et territoires en ex-Yougoslavie, 1945-199o. (Unpublished dostoral dissertation). Ecole des Hautes Etudes en Sciences Sociales, Paris.

Mrdjen, S. (200ob). Les mariages inter-ethniques en ex-Yougoslavie (The inter-ethnic marriages in the former Yugoslavia). Balkan Demographic Papers, 1, 1-17. (in French)

Nejašmić, I. (1990). Česi u Hrvatskoj: kratka analiza suvremenih demografskih procesa [Czechs in Croatia: a short analysis of contemporary demographic processes]. Geografski horizont, 37(2), 33-37. (in Croatian with English summary)

Pepeonik, Z. (1967). Česi u Hrvatskoj. Prilog poznavanju kolonizacije dijela Savsko-dravskog međurječja [Czechs in Croatia. Contribution to the knowledge of colonization of the part of Savsko-Drava intercourse]. Geografski glasnik, 29, 43-59. (in Croatian with English summary)

Petrović, R. (1966). Etnički mešoviti brakovi u Jugoslaviji [Ethnically mixed marriages in Yugoslavia]. Sociologija, 3, 185-200 (in Serbian)
Petrović, R. (1985). Etnički mešoviti brakovi u Jugoslaviji [Ethnically mixed marriages in Yugoslavia]. Beograd: Institut za sociološka istraživanja Filozofskog fakulteta. (in Serbian)

Petrović, R. (1989). Etnogenetski procesi u SR Srbiji [Ethnogenetically processes in SR Serbia]. Gledišta, 7-9, 164-175. (in Serbian with English summary)

Petrović, M.Z. (1997). Etnički homogeni i etnički heterogeni brakovi u Srbiji [Ethnic homogeneous and ethnically heterogeneous marriages in Serbia]. Teme, 20(3-4), 265-276. (in Serbian with English summary)

Qian, Z. (1997). Breaking the racial barriers: Variations in interracial marriage between 1980 and 1990. Demography, 34(2), 263-276. doi:10.2307/2061704

Qian, Z., Glick, J.E., \& Baston, C. (2012). Crossing Boundaries: Nativity, Ethnicity, and Mate Selection. Demography, 49(2), 651-675. doi:10.1007/s13524-012-0090-3

Rodrìguez-Garcìa, D. (2012). Considération théoricométhodologiques autour de la mixité. Enfance, Famille, Générations, 17, 41-58. doi:10.7202/1013414ar

Rodrìguez-Garcìa, D. (2015). Intermarriage and Integration Revisited: International Experiences and Cross-Disciplinary Approaches. The ANNALS of the American Academy of Political and Social Science, 622 (1), 8-36. doi:10.1177/0002716215601397

Rosenfeld, M.J. (2001). The salience of pan-national Hispanic and Asian identities in U:S. marriage markets. Demography, 38(2), 161-175. doi: 10.1353/ dem.2001.0020

Rosenfeld, M.J. (2002). Measures of Assimilation in the Marriage Market: Mexican Americans 19701990. Journal of Marriage and Family, 64(1), 152-162. doi:10.1111/j.1741-3737.2002.00152.x

Rosenfeld, M.J. (2008). Racial, Educational, and Religious Endogamy in the United States: A comparative Historiacal Perspective. Social Forces, 8(1), 1-32. doi:10.1353/sof.o.0077

Smits, J. (2010). Ethnic Intermarriage and Social Cohesion. What can We Learn from Yugoslavia? Social Indicators Research, 96(3), 417-432. doi: 10.1007/ s11205-009-9485-y

Soroko, E. (2014). Ethnically mixed families in the Russian Federation. Demographic Review, 1(4), 96-123.

Tatalović, S. (2005). National Minorities in Croatia. Split: Stina. 170 pp. (in Croatian, with English summary).

Van Tubergen, F., Maas, I. (2007). Ethnic intermarriage among imigrants in the Netherlands. Social Science Research, 36, 1065-1086. doi:10.1016/j.ssresearch.2006.09.003

Vodvarka, A. (1993). Demografska situacija područja općine Daruvar od prvog popisa do 1991. godine [The demographic situation of the area of Daruvar municipality since the first census until 1991]. Přehled kulturních, literárních a školních otázek, 14, 3-20. (in Czech) 